\title{
Effects of some activator and fungicide applications on pollen morphology and anatomy in Cucumis sativus $\mathrm{L}$.
}

Aylin E. Dereboylu ${ }^{1}$

Ulash Ughuz

Department of Biology, Section of Botany, Faculty of Science, University of Ege, 35100-Bornova-Izmir, Turkey

Abstract: In this study, the effects of Forum Blu WP 40 (40\% copper oxichloride, and $6 \%$ dimethomorph) and Anvil SC 50 (50 \% Hexaconazole) fungicides and CropSet activator on morphological and anatomical features of (Cucumis sativus L.) pollens were investigated. Preparations were applied on $C$. sativus seedlings grown in pots in greenhouses as in the concentrations of recommended dose (R.D.) $\left(300 \mathrm{~g} / 1001 \mathrm{H}_{2} \mathrm{O}, 40 \mathrm{cc} / 100\right.$ $\left.1 \mathrm{H}_{2} \mathrm{O}, 60 \mathrm{ml} / 1001 \mathrm{H}_{2} \mathrm{O}\right)$, R.D.x2 (600g/100 $1 \mathrm{H}_{2} \mathrm{O}, 80$ $\left.\mathrm{cc} / 1001 \mathrm{H}_{2} \mathrm{O}, 120 \mathrm{ml} / 1001 \mathrm{H}_{2} \mathrm{O}\right)$ and R.D.x3 (900g/100 $1 \mathrm{H}_{2} \mathrm{O}, 120 \mathrm{cc} / 1001 \mathrm{H}_{2} \mathrm{O}, 180 \mathrm{ml} / 1001$ water). The lengths and the diameters of pollens in Equatorial view and Polar view, the thickness of exine-intine layers, lengths and diameters of the pores, length of the one side of the triangular polar area in Equatorial View and pollen shapes were measured with the micrometric ocular. When the control group and all the application groups were compared according to the data obtained, there was an increase in the lengths and the diameters of pollens in equatorial view and polar view, which was not consistent with the dose increase. The percentage of fertile pollens in all the application groups decreased as compared to control group, which was consistent with the dose increase. As compared to control group, exine layers increased while intine layers decreased. Pore lengths and diameters, and length of the one side of the triangular polar area values increased as compared to control group. It was observed that the applications caused more toxic effects as related with the increases in the dose. Moreover, the pollen shapes determined in the control group changed in all the groups except for the Anvil (40 ml/100 1 water) and crop-set (180 ml/100 1 water) groups.

Key Words: Cucurbitaceae, flowers, morphology, plant activator, pollen

'E-mail: aylin.esiz.dereboylu@ege.edu.tr

Received 08.11.2021; Received in revised form 19.11.2021; Accepted 25.11.2021

\section{INTRODUCTION}

Since the agriculture was introduced into human beings' life, agricultural production has been performed through natural methods, which has had no negative effects on the ecosystem. Although the world's population has increased rapidly, food production has fallen behind the population increase, as a result of which all countries have faced the fact that they have to increase food production rapidly. In order to solve the problem, first of all, agricultural products should be protected against diseases and production losses should be prevented. In order to solve these problems, the first thing applied has been the use of chemical preparations, the most widespread of which are fungicides. It is a known fact that fungicides are commonly used in agricultural production all over the world in order to keep the diseases under control [Bromilow et al., 1987].

Indiscriminate use of pesticides can create a potential risk like the use of any toxin. It is a well known fact that imperfect and widespread uses of these chemicals can have phytotoxic affects on plants, cause degenerations in anatomical [Siegfriend, 1999] and morphological structures of the plants, effect physiological conditions such as decrease in photosynthesis and transpiration processes [Dvorak, Remesova, 2001; Radestksi et al., 2000] inhibit pollen germination [Padilla et al., 2017; Pavlik, Jandurova, 2000] and affect fruit set [Fell et al., 1983], as a result of the effects they affect the production negatively, and have negative effects on human beings and animal through the food chain.

The effects of pesticides on pollens have been investigated several times. It was determined that pesticides increased the rate of chromosomal abnormalities affecting pollen viability [Zambon et al., 2018]. When the combined effects of an organophosphorus insecticide and dinitro herbicide were investigated it was found that pollen vitality decreased by $60 \%$ [Dubey et al., 1984]. It was also reported that the intensive use of fungicides may have negative effects on pollen germination and fruit set while fruit trees are blooming [Fell et al., 1983; Marcucci, Filiti, 1984; Redalen, 1980]. 
In this study, the effects of Forum Blu and Anvil fungicides and Crop-Set, a plant activator, recently introduced into the market, on morphology and anatomy of Cucumis sativus L. pollens were investigated.

\section{MATERIAL AND METHODS}

In the study, Gordion F1 seeds were used, which are the most preferred in cucumber production. Anvil SC 50 (50\% Hexaconazole) was used against powdery mildew, Forum Blu WP 40 (40 \% copper oxichloride, 6 $\%$ dimethomorph) was used against downy mildew and Crop-Set EC (Lactobacillus acidiophilus fermentation product and plant extract, mineral matter), commonly used as a plant activator in recent years was applied on seedlings. Applications were at the recommended dose (R.D.), R.D.x2 and R.D.x3 and were performed four times at 15-day intervals early in the morning (Tab. 1). There were ten groups (one control group and nine application groups) including 210 seedlings.

Table 1. Application dozes of the substances used in this study.

\begin{tabular}{|c|c|c|c|}
\hline $\begin{array}{l}\text { Chemicals } \\
\text { applied }\end{array}$ & \multicolumn{2}{|c|}{ Applied dosage } & $\begin{array}{c}\text { Recommended } \\
\text { dosage }\end{array}$ \\
\hline \multirow{3}{*}{$\begin{array}{l}\text { Anvil SC } \\
50\end{array}$} & R.D & $0.4 \mathrm{ml} / 1 \mathrm{~L}$ water & $40 \mathrm{ml} / 100 \mathrm{~L}$ water \\
\hline & R.Dx2 & $0.8 \mathrm{ml} / 1 \mathrm{~L}$ water & \\
\hline & R.Dx3 & $1.2 \mathrm{ml} / 1 \mathrm{~L}$ water & \\
\hline \multirow{2}{*}{$\begin{array}{l}\text { Forum Blu } \\
\text { WP } 40\end{array}$} & R.D & $3 \mathrm{~g} / 1 \mathrm{~L}$ water & $300 \mathrm{~g} / 100 \mathrm{~L}$ water \\
\hline & $\begin{array}{l}\text { R.Dx2 } \\
\text { R.Dx3 }\end{array}$ & $\begin{array}{l}6 \mathrm{~g} / 1 \mathrm{~L} \text { water } \\
9 \mathrm{~g} / 1 \mathrm{~L} \text { water }\end{array}$ & \\
\hline \multirow{2}{*}{$\begin{array}{l}\text { Crop-Set } \\
\text { EC }\end{array}$} & R.D & $0.6 \mathrm{ml} / 1 \mathrm{~L}$ water & $60 \mathrm{ml} / 100 \mathrm{~L}$ water \\
\hline & $\begin{array}{l}\text { R.Dx2 } \\
\text { R.Dx3 }\end{array}$ & $\begin{array}{l}1.2 \mathrm{ml} / 1 \mathrm{~L} \text { water } \\
1.8 \mathrm{ml} / 1 \mathrm{~L} \text { water }\end{array}$ & \\
\hline
\end{tabular}

Flower samples for the pollen analyses were collected early in the morning a week before the last pesticide application. The samples were fixed in carnoy reactive (3:1, 96\% ethanol: glacial acetic acid) and kept in a refrigerator until the preparations were ready.

Flower samples removed from Carnoy reactive and then the anthers taken from ripe floral buds with the help of a dissection needle were mounted on glycerine-gelatinliquid safranine mixture [Wodehouse, 1965].

In the preparations, the lengths and the diameters of 100 pollens from each group were measured in equatorial and polar views. Measurements were performed with the "Prior" microscope with the help of the micrometric ocular. In order to determine the fertile and sterile pollen percentages, the number of fertile and sterile pollens was counted in 100 pollens belonging to each application group. Different sterile pollen types were photographed with the "Olympus" microscope. Exine and intine thicknesses of 50 pollens in each group in equatorial view, and pore lengths and widths of the pollens in polar view were measured with the micrometric ocular. Length of the one side of the triangular polar area measurements of the pollens in equatorial view were performed with micrometric ocular too. The data obtained in our study were evaluated according to $\mathrm{p}<0.05$ importance scale with variance analysis using the IBM SPSS version 20.0.

\section{RESULTS AND DISCUSSION}

Fertile organs in flowers are more sensitive to stress conditions than vegetative parts of plants especially during the development period. [Dorion et al., 1996; Saini, 1997; Xiong, Peng, 2001]. Therefore, pollens, except for plants grown in vitro, are considered the most suitable biological material for the evaluation of toxic effects of xenobiotics [Bromilow et al., 1987; Chamberlain, 1984; Cox, 1988]. There study suggests that fungicides may have negative effects on pollen germination, thus on fruit development, due to the increase in doses [Pavlik, Jandurova, 2000]. Most of those studies are focused on xenobiotics such as fungicides tested for pollen germination [He, Wetzstein, 1994]. In vitro germination studies conducted on pollens treated with fungicides reveal that pollen tubes and other parts are deformed and that there is a decrease in pollen germination [Pavlik, Jandurova, 2000].

The sizes, shapes and exine characteristics of Cucurbitaceae pollens are changeable. There are different pollen types depending on aperture, some examples of which are triporate, pentaporate, tricolpoidate, tricoplate, zonocolpate. Echinate and reticulate are their ornamentation [Garcia et al., 2003]. The pollens of Cucumis are triporate structure depending on the aperture [Kesercioğlu, 1978; Şensoy et al., 2003].

When the results we obtained are evaluated, it was seen that all the parameters in the Anvil application groups increased more than those in the control group in the recommended dose (Tab. 2). However, if the dose was increased, the scores decrease, but they were still higher than the scores in the control group. These increases were statistically significant $(p<0.05)$. In Forum Blu and Crop-Set application groups almost all parameters increased too and these increases were also statistically significant $(\mathrm{p}<0.05)$.

It is well known that in several plants the pollen size and the amount of pollens per flower may differ 
Table 2. Length and width measurements of pollens in equatorial and polar view $(\mu \mathrm{m})$.

\begin{tabular}{lllll}
\hline \hline \multicolumn{1}{c}{ Application } & \multicolumn{2}{c}{ Equatorial view } & \multicolumn{2}{c}{ Polar view } \\
\cline { 2 - 5 } \multicolumn{1}{c}{ Groups } & \multicolumn{1}{c}{ Width $(\mu \mathrm{m})$} & \multicolumn{1}{c}{ Length $(\mu \mathrm{m})$} & Width $(\mu \mathrm{m})$ & \multicolumn{1}{c}{ Length $(\mu \mathrm{m})$} \\
\hline Control & $51.30 \pm 0.125$ & $56.90 \pm 0.132$ & $44.62 \pm 0.151$ & $57.10 \pm 0.161$ \\
Anvil R.D. & $52.22 \pm 0.941$ & $60.77 \pm 0.950^{\mathrm{a}}$ & $48.97 \pm 0.103^{\mathrm{a}}$ & $60.05 \pm 0.101^{\mathrm{a}}$ \\
Anvil R.Dx2 & $50.90 \pm 0.116$ & $60.40 \pm 0.929^{\mathrm{a}}$ & $48.07 \pm 0.951^{\mathrm{a}}$ & $59.52 \pm 0.960^{\mathrm{a}}$ \\
Anvil R.Dx3 & $51.15 \pm 0.673$ & $59.20 \pm 0.664^{\mathrm{a}}$ & $47.92 \pm 0.964^{\mathrm{a}}$ & $59.17 \pm 0.841^{\mathrm{a}}$ \\
ForumBlu R.D. & $49.92 \pm 0.846^{\mathrm{a}}$ & $57.15 \pm 0.114$ & $47.20 \pm 0.977^{\mathrm{a}}$ & $57.87 \pm 0.111$ \\
ForumBlu R.Dx2 & $52.05 \pm 0.988$ & $60.70 \pm 0.106^{\mathrm{a}}$ & $42.60 \pm 0.118^{\mathrm{a}}$ & $60.20 \pm 0.981^{\mathrm{a}}$ \\
ForumBlu R.Dx3 & $50.75 \pm 0.101$ & $58.60 \pm 0.956^{\mathrm{a}}$ & $46.45 \pm 0.747^{\mathrm{a}}$ & $57.15 \pm 0.914$ \\
Crop-Set R.D & $52.87 \pm 0.101^{\mathrm{a}}$ & $61.82 \pm 0.972^{\mathrm{a}}$ & $48.85 \pm 0.968^{\mathrm{a}}$ & $60.50 \pm 0.942^{\mathrm{a}}$ \\
Crop-Set R.Dx2 & $52.35 \pm 0.113$ & $60.80 \pm 0.109^{\mathrm{a}}$ & $48.35 \pm 0.794^{\mathrm{a}}$ & $59.62 \pm 0.880^{\mathrm{a}}$ \\
Crop-Set R.Dx3 & $53.37 \pm 0.783^{\mathrm{a}}$ & $61.90 \pm 0.767^{\mathrm{a}}$ & $50.25 \pm 0.846^{\mathrm{a}}$ & $61.92 \pm 0.750^{\mathrm{a}}$ \\
\hline
\end{tabular}

Note: The difference between "a" and control group is statistically important $(\mathrm{p}<0.05)$. R.D.: Recommended dose, R.D.x2: Double the recommended dosage, R.D.x3: Three times the recommended dose.

and these changes may result from environmental factors [Cruzan, 1990; Nakamura, Wheeler, 1992]. It is reported that, in beans exposed to high temperatures, there may be increases in the number of the pollens with large vacuole and abnormally big morphology [Gross, Kigel, 1994] and in the number of small and wrinkled pollens [Porch, Jahn, 2001]. It is also reported that there may be increases in the sizes of some genera pollens of Cucurbitaceae family resulting from ploidy and decreases in further stages [Kesercioğlu, 1978, 1985]. In our study, we also consider that the changes occurring in the sizes of the pollens may result from the chemicals used.

Y. He and H.Y. Wetzstein [1994] showed that fungicide applications in early stages led to delays in the development of willow flowers and leaves, and deterioration of the pollens. It was also reported that when commercial fungicides such as captan, dinocap, sulfur, and triforine were sprayed on anthers of certain apple cultivars, the vitality of the pollens decreased. The presence of brown, gray, translucent, or deformed pollens was the indicator of decrease in pollen vitality [Churc, Williams, 1978]. Pollen vitality were considered as the main factors limiting fruit development [Koti et al., 2004] under environmental factors such as, high temperature stress [Peet et al., 1998], pesticide stress [Dubey et al., 1984], and heavy metal stress [Xiong, Peng, 2001]. In the study performed by Suzuki et al. [2001], it was seen that the temperature stress applied about ten days before the blooming of Phaseolus vulgaris L. encouraged pollen sterility. The first structural changes in anthers exposed to high temperature stress are seen in endoplasmic reticulum at tapetum. It was reported that high temperature effected ER structure, limited its function at tapetum and thus pollen sterility could be associated with tapetal degeneration.

The usual response to several environmental stresses in pollens is the starch deficiency. Sheron and Saini [1996] observed a decrease in starch accumulation in rice pollens under water stress. It was reported that sterile pollens developed in anemophile plants such as Graminae due to the increase in starch deficiency although the number of the pollens were high [Schoene et al., 2004].

In our study, when percentages of fertility values were considered, there was a decrease in all the application groups compared to the control group (Tab. 3). These decreases were parallel with the increases in dose have merited attention. When percentages of fertility scores were compared with the control group, the Crop-Set application groups showed the lowest scores. In the application groups, we observed several sterile pollen types such as wrinkled, unstained, invisible pore and abnormally shaped pollens (Fig. 1).

The most common sterile pollen types were the abnormally shaped pollens when all the application groups were considered. The groups affected most were the Anvil application groups when percentages of fertility values were considered. Our findings were consistent with the data in the literature.

In another study performed on rice exposed to aluminum stress, it was observed that the percentage of fertile pollens dropped from $90 \%$ to $35 \%$ in the control group. In order to determine the pollen vitality, KI solution was used and fertile pollens were stained blue but sterile pollens were not stained [Mohanty et al., 2004]. Heavy metals such as aluminum, copper and cadmium are known to be effective on pollen 
Table 3. Pollen fertility of the control and application groups.

\begin{tabular}{lcccccc}
\hline \hline \multicolumn{1}{c}{ Groups } & $\begin{array}{c}\text { Fertile } \\
\text { Pollen } \\
(\%)\end{array}$ & $\begin{array}{c}\text { Wrinkled } \\
\text { pollen } \\
(\%)\end{array}$ & $\begin{array}{c}\text { Unstained } \\
\text { pollen } \\
(\%)\end{array}$ & $\begin{array}{c}\text { Pollen with } \\
\text { unvisible pore } \\
(\%)\end{array}$ & $\begin{array}{c}\text { Pollen with } \\
\text { abnormal } \\
\text { shape (\%) }\end{array}$ & $\begin{array}{c}\text { Total sterile } \\
\text { pollen }(\%)\end{array}$ \\
\hline Control & 85 & 7 & 0 & 1 & 7 & 15 \\
Anvil R.D & 54 & 6 & 0 & 2 & 38 & 46 \\
Anvil R.Dx2 & 53 & 15 & 5 & 1 & 26 & 47 \\
Anvil R.Dx3 & 52 & 15 & 1 & 1 & 31 & 48 \\
ForumBlu R.D & 56 & 14 & 0 & 5 & 25 & 44 \\
ForumBlu R.Dx2 & 62 & 13 & 0 & 1 & 24 & 38 \\
ForumBlu R.Dx3 & 50 & 13 & 2 & 1 & 5 & 50 \\
Crop-Set R.D & 90 & 4 & 0 & 1 & 6 & 10 \\
Crop-Set R.Dx2 & 87 & 6 & 0 & 0 & 8 & 13 \\
Crop-Set R.Dx3 & 87 & 5 & 0 & & 0 & 13 \\
\hline
\end{tabular}

Note: R.D.: Recommended dose, R.D.x2: Double the recommended dosage, R.D.x3: Three times the recommended dose.

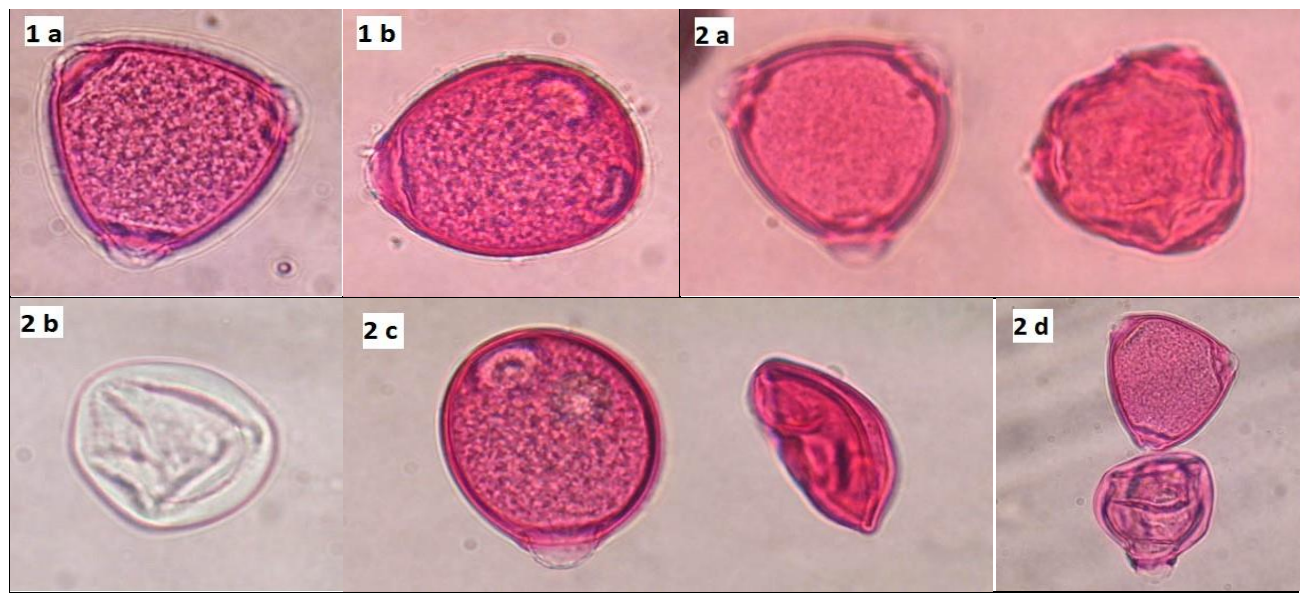

Figure 1. Fertile pollen in control group: 1a. equatorial view $(6,3 \times 20), 1 \mathrm{~b}$. polar view (6,3x20); Sterile pollen types in application groups: 2a. Crop-Set R.Dx3 group, wrinkled sterile pollen $(6.3 \times 20), 2$ b. Forum Blu R.Dx3 groups, unstained sterile pollen (6.3x20), 2c. Forum Blu R.D. groups, wrinkled sterile pollen (6.3x20), 2d. Anvil R.Dx3 groups, wrinkled sterile pollen $(6,3 \times 20)$.

germination and tube development even at low concentrations [Xiong, Peng, 2001].

When the exine thickness of the pollens belonging to the control and application groups was investigated, there were statistically significant increases in all the application groups as compared to control group. The highest increases in exine values were in the Crop-Set application groups. These increases in the application groups which are parallel with the increases in dose has great importance. It was determined that there were differences in pollen exine ornamentations in bean genotypes under high temperatures and that the ultrastructure of pollen cell wall was changed. Although the pollens had ectexine (columellae+tapetum), it was seen that an additional layer was formed. It was also reported that environmental stresses such as high temperatures seen as immaturity in tetrates or clusters of pollens or abnormal exine ornamentation were the indicators of abnormal tapetal function [Porch, Jahn, 2001].

UV-B radiation was applied to soybeans, and flower and pollen morphologies and pollen germination characteristics were evaluated. Increased UV-B radiation levels led to abnormally shaped pollens in all the genotypes. There were wrinkled pollens and abnormalities in the exine structure in the majority of pollen grains [Koti et al., 2004]. When the intine values are considered, there are statistically insignificant decreases in all the application groups compared with the control group (Tab. 4). In a study conducted on wheat, it is reported that water stress leads to starch deficiency in the anther as a result of thinning or elimination of the intine layer [Lalonde et al., 1997].

Pore lengths and widths of the pollens in the control and application groups were made in the polar view. When the pore lengths were considered, there was an 
Table 4. Exine and intine measurements $(\mu)$ of the pollens.

\begin{tabular}{lcc}
\hline \hline \multirow{2}{*}{ Treatment } & \multicolumn{2}{c}{ Equatorial view } \\
\cline { 2 - 3 } & \multicolumn{1}{c}{ Exine $(\mu)$} & Intine $(\mu)$ \\
\hline Control & $2.400 \pm 0.311$ & $0.975 \pm 0.075$ \\
Anvil (0.4 ml/1L water) & $2.670 \pm 0.296^{\mathrm{a}}$ & $0.930 \pm 0.124$ \\
Anvil $(0.8 \mathrm{ml} / 1 \mathrm{~L}$ water) & $2.815 \pm 0.219^{\mathrm{a}}$ & $0.930 \pm 0.113$ \\
Anvil $(1.2 \mathrm{ml} / 1 \mathrm{~L}$ water) & $2.840 \pm 0.230^{\mathrm{a}}$ & $0.955 \pm 0.097$ \\
Forum Blu (3 g/1L water) & $2.320 \pm 0.272$ & $0.925 \pm 0.145$ \\
Forum Blu (6 g/1 L water) & $2.540 \pm 0.461$ & $0.970 \pm 0.082$ \\
Forum Blu (9 g/1 L water) & $2.590 \pm 0.302^{\mathrm{a}}$ & $0.930 \pm 0.113$ \\
Crop-Set $(0.6 \mathrm{ml} / 1 \mathrm{~L}$ water) & $2.880 \pm 0.253^{\mathrm{a}}$ & $0.935 \pm 0.110$ \\
Crop-Set $(1.2 \mathrm{ml} / 1 \mathrm{~L}$ water) & $2.885 \pm 0.161^{\mathrm{a}}$ & $0.950 \pm 0.101$ \\
Crop-Set $(1.8 \mathrm{ml} / 1 \mathrm{~L}$ water) & $2.955 \pm 0.186^{\mathrm{a}}$ & $0.970 \pm 0.082$ \\
\hline
\end{tabular}

increase in all the application groups as compared to control group. These increases were significant in Anvil R.D, Forum Blu R.Dx2, Crop-Set R.D and Crop-Set R.Dx3 application groups (Tab. 5). The highest value was attained in the Crop-Set R.Dx3 in comparison with the control group.

Table 5. Measurements of pores $(\mu)$ in polar view.

\begin{tabular}{llc}
\hline \hline & \multicolumn{2}{c}{ Polar view } \\
\cline { 2 - 3 } & \multicolumn{1}{c}{ Pore width } & $\begin{array}{c}\text { Pore length } \\
(\mu)\end{array}$ \\
\hline Control & $10.125 \pm 0.144$ & $12.525 \pm 0.169$ \\
Anvil $(0.4 \mathrm{ml} / 1 \mathrm{~L})$ & $10.775 \pm 0.155^{\mathrm{a}}$ & $12.675 \pm 0.138$ \\
Anvil $(0.8 \mathrm{ml} / 1 \mathrm{~L})$ & $10.650 \pm 0.148$ & $12.600 \pm 0.106$ \\
Anvil $(1.2 \mathrm{ml} / 1 \mathrm{~L})$ & $10.525 \pm 0.124$ & $12.775 \pm 0.096$ \\
Forum Blu (3 g/1L) & $10.475 \pm 0.142$ & $13.000 \pm 0.155$ \\
Forum Blu (6 g/1 L) & $10.850 \pm 0.140^{\mathrm{a}}$ & $13.000 \pm 0.155$ \\
Forum Blu (9 g/1 L) & $10.400 \pm 0.130$ & $12.650 \pm 0.131$ \\
Crop-Set (0.6 ml/1 L) & $10.525 \pm 0.156$ & $12.725 \pm 0.111$ \\
Crop-Set (1.2 ml/1L) & $10.975 \pm 0.148^{\mathrm{a}}$ & $12.950 \pm 0.117$ \\
Crop-Set (1.8 ml/1L) & $11.150 \pm 0.159^{\mathrm{a}}$ & $13.200 \pm 0.102^{\mathrm{a}}$ \\
\hline
\end{tabular}

When the pore width measurements were considered, there was an increase in all the application groups compared with the control group, which was not parallel with the increase in the dose. The highest increase was obtained in the Crop-Set R.Dx3 in comparison with
Table 6. Measurements of length of one side of the triangular polar area $(\mu)$ in equatorial view, $t$ : length of one side of the triangular polar area.

\begin{tabular}{lc}
\hline \hline \multirow{2}{*}{ Treatment } & Equatorial view \\
\cline { 2 - 2 } & $\mathrm{t}(\mu)$ \\
\hline Control & $33.500 \pm 0.283$ \\
Anvil $(0.4 \mathrm{ml} / 1 \mathrm{~L})$ & $34.425 \pm 0.288$ \\
Anvil $(0.8 \mathrm{ml} / 1 \mathrm{~L})$ & $33.575 \pm 0.307$ \\
Anvil $(1.2 \mathrm{ml} / 1 \mathrm{~L})$ & $34.175 \pm 0.219$ \\
Forum Blu $(3 \mathrm{~g} / 1 \mathrm{~L})$ & $33.370 \pm 0.281$ \\
Forum Blu $(6 \mathrm{~g} / 1 \mathrm{~L})$ & $34.625 \pm 0.242$ \\
Forum Blu $(9 \mathrm{~g} / 1 \mathrm{~L})$ & $34.100 \pm 0.208$ \\
Crop-Set $(0.6 \mathrm{ml} / 1 \mathrm{~L})$ & $37.000 \pm 0.228^{\mathrm{a}}$ \\
Crop-Set $(1.2 \mathrm{ml} / 1 \mathrm{~L})$ & $37.950 \pm 0.198^{\mathrm{a}}$ \\
Crop-Set $(1.8 \mathrm{ml} / 1 \mathrm{~L})$ & $38.475 \pm 0.240^{\mathrm{a}}$ \\
\hline
\end{tabular}

Note: The difference between "a" and control group is statistically important $(\mathrm{p}<0.05)$.

the control group, and it was statistically significant $(\mathrm{p}<0.05)$.

Length of the one side of the triangular polar area measurements in equatorial view were also performed both in the control and application groups. As was seen in the table 6 , in almost all the application groups an increase was observed compared with the control group; however, except for the Crop-Set group, the increases were not parallel with the dose increases. The highest increase was obtained in the Crop-Set application group in comparison with the control group, and it was statistically significant $(\mathrm{p}<0.05)$. One of the important parameters which reveal the effects of fungicides on pollens is the pollen morphology. When the pollen morphologies of the control group and application groups were compared, it was observed that pollen shapes in the application groups were different from those in the control group except for the CropSet $\left(180 \mathrm{ml} / 1001 \mathrm{H}_{2} \mathrm{O}\right)$ and Anvil $\left(40 \mathrm{cc} / 100 \mathrm{~L} \mathrm{H}_{2} \mathrm{O}\right)$ groups, and that the oblate spheroidal shape turns into the prolatspherodial shape (Tab. 7).

Table 7. Pollen shape classification in the control and application groups.

\begin{tabular}{lcccc}
\hline \hline Treatment & P (Polar axis) & E (Equatorial axis) & P/E & Pollen shape \\
\hline Control & 56.90 & 57.10 & 0.996 & Oblate spheroidal \\
Anvil $(0.4 \mathrm{ml} / 1 \mathrm{~L})$ & 60.77 & 60.05 & 1.011 & Oblate spheroidal \\
Anvil $(0.8 \mathrm{ml} / 1 \mathrm{~L})$ & 60.40 & 59.52 & 1.014 & Prolate spheroidal \\
Anvil $(1.2 \mathrm{ml} / 1 \mathrm{~L})$ & 59.20 & 59.17 & 1.000 & Prolate spheroidal \\
Forum Blu $(3 \mathrm{~g} / 1 \mathrm{~L})$ & 57.15 & 57.87 & 0.987 & Prolate spheroidal \\
Forum Blu $(6 \mathrm{~g} / 1 \mathrm{~L})$ & 60.70 & 60.20 & 1.008 & Prolate spheroidal \\
Forum Blu $(9 \mathrm{~g} / 1 \mathrm{~L})$ & 58.60 & 57.15 & 1.025 & Prolate spheroidal \\
Crop-Set $(0.6 \mathrm{ml} / 1 \mathrm{~L})$ & 61.82 & 60.50 & 1.021 & Prolate spheroidal \\
Crop-Set $(1.2 \mathrm{ml} / 1 \mathrm{~L})$ & 60.80 & 59.62 & 1.019 & Prolate spheroidal \\
Crop-Set $(1.8 \mathrm{ml} / 1 \mathrm{~L})$ & 61.90 & 61.92 & 0.999 & Oblate spheroidal \\
\hline
\end{tabular}


It is known that fungicides have negative effects on the morphological and anatomical structures of pollens. As the data obtained in our study support, it can be suggested that chemicals may negatively affect the morphological and anatomical structures of pollens, which may, in turn, affect fruit development.

\section{ACKNOWLEDGMENTS}

The authors thank to Ege University (BAP Project No. 2001 FEN 009) for financial support during this study. This work is part of a $\mathrm{PhD}$ thesis.

\section{REFERENCES}

Bromilow R.H., Rigitano R.L.O., Briggs G.G., Chamberlain K. (1987) Phloem translocation of nonionised chemicals in Ricinus communis. Pesticide Science, 19: 85-99.

Chamberlain K., Burrell M.M., Butcher D.N., White J.C. (1984) Phloem transport of xenobiotics in Ricinus communis var. gibsonii. Pesticide Science, 15: 1-8.

Churc B.M., Williams R.R. (1978) The toxicity to apple pollen in the Anther. Journal of Horticultural Science, 53: 91-94.

Cox R.M. (1988) The sensitivity of pollen from various coniferous and broad-leaved tress to combinations of acidity and trace metals. New Phytologist, 109: 193-201.

Cruzan M.B. (1990) Variation in pollen size, fertilization ability, post-fertilization siring ability in Eryhronium grandiflorum. Evolution, 44: 843-856.

Dorion S., Lalonde S., Saini H.S. (1996) Induction of male sterility in wheat by meiotic-stage deficit is preceded by a decline in invertase activity and changes in carbohydrate metabolism in anthers. Plant Physiology, 111(1): 137-145.

Dubey P.S., Shrivastava A., Shevade A. (1984) Pesticidal toxicity bioassay with pollen damage. Environmental Pollution Series A, Ecological and Biological, 34(4): 293-295.

Dvorak J., Remesova I. (2001) Determination of phytotoxic effects of pre-emergence herbicides using a technigue of very rapid fluorescence induction. Rostlinna Vyroba, 47(2): 91-95.

Fell R.D., Rajotte E.G., Yoder K.S. (1983) Effects of fungicides sprays during apple bloom on pollen viability and honey bee foraging. Environmental Entomology, 12: 1572-1575.

Garcia D.L.Q., Hernandez C.L., Luz M., Sanchez A.
(2003) Morfology of the pollen grains of the family Cucurbitaceae of the state of Queretaro, Mexico. Polibotanica, 16: 29-48.

Gross Y., Kigel J., (1994) Differential sensitivity to high temperature of stages in the reproductive development of common bean (Phaseolus vulgaris L.). Field Crops Research, 36: 201-212.

He Y., Wetzstein H.Y. (1994) Pollen degeneration and retarded leaf development from fungicidal sprays applied during microspore development and shoot expension. Journal of Horticultural Science, 69: 975-983.

Kesercioğlu T. (1978) C. melo türü ve Türkiye'de yetiştirilen kültür formlarının polen analizleri ve morfolojik yapıları. Ege Üniversitesi Fen Fakültesi Dergisi Seri B, 2(2): 143-148.

Kesercioğlu T. (1985) Batı Anadolu'da bulunan ve kültürü yapılan Cucumis formları üzerinde sitotaksonomik araştırmalar. Anatolia, Doğa Bilim Dergisi, Seri A, Cilt 9, Say1 1.

Koti S., Reddy K.R., Kakani V.G., Zhao D., Reddy V.R. (2004) Soybean (Glycine max) pollen germination characteristics, flower and pollen morphology in response to enhanced ultraviolet-B radiation. Annals of Botany, 94: 855-864.

Lalonde S., Beebe D.U., Saini H.S. (1997) Early signs of disruption of wheat anther development associated with the induction of male sterility by meiotic-stage water deficit. Sexual Plant Reproduction, 10: 40-48.

Marcucci M.C., Filiti N. (1984) Germination of pear and apple pollen as influenced by fungicides. Garten bauwiss ecschaft, 49: 28-32.

Mohanty S., Das A.B., Das P., Mohanty P. (2004) Effects of a low dose of aluminyum on mitotic and meiotic activity, 4C DNA content, and pollen sterility in rice, Oryza sativa L. cv. Lalat. Ecotoxicology and Environmental Safety, 59: 70-75.

Nakamura R.R., Wheeler N.C. (1992) Pollen competition and paternal success in douglas fir. Evolution, 46: 846-851.

Padilla F., Soria N., Oleas A., Rueda D., Manjunatha B., Kundapur R.R., Maddela N.R., Rajeswari B. (2017) The effects of pesticides on morphology, viability, andgermination of Blackberry (Rubus glaucus Benth.) and tree tomato (Cav.) pollen grains. 3 Biotech, 7: 1-12.

Pavlik M., Jandurova O.M. (2000) Fungicides cytotoxicity expressed in male gametophyte development in Brassica campestris after in vitro 
application of converted field doses. Environmental and Experimental Botany, 44: 49-58.

Peet M.M., Willits D.H., Gardner R.G. (1998) Comparing heat stres effects on male-fertilite and male-sterile tomatoes. Plant, Cell and Environment, 21: 225-231.

Porch T.G., Jahn M. (2001) Effects of high-temperature stres on microsporogenesis in heat-tolerant genotypes of Phaseolus vulgaris. Plant Cell and Environment, 24: 723-731.

Radestksi C.M., Cotelle S., Ferard J.F. (2000) Classical and biochemical endpoints in the evalution of phytotoxic effects caused by the herbicide trichloroacetate. Environmental and Experimental Botany, 44: 221-229.

Redalen G. (1980) Effect of fungicides on pollen germination and fruit set in raspberries. Gartenbauwissenschsaft, 45: 248-251.

Saini H.S (1997) Effects of water stres on male gametophyte development in plants. Sexual Plant Reproduction, 10: 67-73.

Schoene K., Franz J.Th., Masuch G. (2004) The Effect of ozone on pollen development in Lolium perene L. Environmental Pollution, 131: 347-354.

Sheoran I.S., Saini H.S. (1996) Drought-induced male sterility in rice: changes in carbohydrate levels and enzyme activity associated with the inhibition of starch accumulation in pollen. Sexual Plant Reproduction, 9: 161-169.

Siegfriend F. (1999) Pathological and Regenerative Plant Anatomy. 1095 pp. Gebrüder Borntraeger, Berlin, Stuttgart.

Suzuki K., Takeda H., Tsukaguchi T., Egawa Y. (2001) Ultrastructural study on degeneration of tapetum in anther of snap bean (Phaseolus vulgaris L.) under heat stres. Sexual Plant Reproduction, 13(6): 293299.

Shensoy A.S., Ercan N., Ayar F., Temirkaynak M. (2003) Determination of some morphological properties and vitality of pollen in some vegetable species in the Cucurbitaceae family. Akdeniz Ün. Ziraat Fak. Dergisi, 16(1): 1-6. [Şensoy A.S., Ercan N., Ayar F., Temirkaynak M. (2003) Cucurbitaceae Familyasındaki bazı sebze türlerinde çiçek tozlarının bazı morfolojik özellikleri ile canlılıklarının belirlenmesi. Akdeniz Ün. Ziraat Fak. Dergisi, 16(1): 1-6]

Xiong Z.T., Peng Y.H. (2001) Response of pollen germination and tube growth to Cadmium with special reference to low concentration exposure. Ecotoxicology and Environmental Safety, 48: 51-55. Wodehouse R.P. (1965) Pollen Grains, Hamer Press, New York, 249.

Zambon C.R., Techio V.H., Fernando L., Oliveira D., De Oliveira A.F., Pio R. (2018) Abnormalities induced by agricultural pesticides in the microsporogenesis of olive tree (Olea europaea L.) cultivars. Plant Biosystems, 153(1): 1-9.

\section{Cucumis sativus L. tozcuq morfologiyası vo anatomiyasına bəzi aktivator və fungisid tətbiqlərinin təsiri}

\section{Aylin E. Dereboylu}

\section{Ulaş Ŭ̆uz}

Biologiya Kafedrası, Botanika bölməsi, Tabiat Elmlari Fakültəsi, Ege Universiteti, 35100-Bornova İzmir, Türkiyo

$\mathrm{Bu}$ araşdırmada tozcuğun (Cucumis sativus L.) morfoloji və anatomik əlamətlərinə Forum Blu WP 40 (mis oksixlorid 40\%, dimetomorf 6\%) va Anvil SC 50 fungisid (50\% heksakonazole) və Crop Set aktivatorunun təsiri tədqiq edilmişdir. İstixanalarda qablarda yetişdirilən $C$. sativus şitillərinə preparatlar tövsiyə olunan dozada uyğun olaraq (RD) (300 q / 100 $\left.\mathrm{L} \mathrm{H}_{2} \mathrm{O}, 40 \mathrm{cc} / 100 \mathrm{~L} \mathrm{H}_{2} \mathrm{O}, 60 \mathrm{ml} / 100 \mathrm{~L} \mathrm{H}_{2} \mathrm{O}\right), \mathrm{RDx} 2$ $\left(600 \mathrm{q} / 100 \mathrm{~L} \mathrm{H}_{2} \mathrm{O}\right) 80 \mathrm{cc} \mathrm{Cm} / 1001 \mathrm{H}_{2} \mathrm{O}, 120 \mathrm{ml} / 100 \mathrm{l}$ $\left.\mathrm{H}_{2} \mathrm{O}\right)$ və R.D.x3 (900 q / $1001 \mathrm{H}_{2} \mathrm{O}, 120 \mathrm{sm} 3 / 1001 \mathrm{H}_{2} \mathrm{O}$, $\left.180 \mathrm{ml} / 1001 \mathrm{H}_{2} \mathrm{O}\right)$ totbiq edilmişdir. Ekvatorial və qütb görünüşlərində tozcuqların uzunluğu və diametri, ekzinintin təbəqələrinin qalınlığ və diametri, ekvatorial görünüşdə üçbucaqlı qütb sahəsinin bir tərəfinin uzunluğu və tozcuqların forması mikrometrik okulyar ilə ölçülmüșdür. Kontrol qrup və bütün tətbiq qruplarından əldə edilmiş nəticələrdəki məlumatlar müqayisə edildikdə, ekvatorial və qütb görünüşlərində tozcuqların uzunluğu və diametrində artım müşahidə edilmişdir ki, bu da dozanın artmasına uyğun gəlmir. Bütün təcrübə qruplarında münbit tozcuq faizi kontrol qrupu ilə müqayisədə azalmışdır ki, bu da dozanın artmasına uyğundur. Kontrol qrupu ilə müqayisədə ekzin təbəqələri artıb, intin təbəqələri isə azalıb. Məsamə uzunluğu və diametri, həmçinin üçbucaqlı qütb sahəsinin bir tərəfinin uzunluğu kontrol qrupu ilə müqayisədə artmışdır. Müşahidə edilmişdir ki, tətbiq dozalarının artması daha çox zəhərli təsirlərə səbəb olur. Bundan əlavə, nəzarət qrupunda müəyyən edilmiş tozcuqların forması Anvil $\left(40 \mathrm{ml} / 1001 \mathrm{H}_{2} \mathrm{O}\right)$ və 
Crop-Set qruplarından başqa $\left(180 \mathrm{ml} / 1001 \mathrm{H}_{2} \mathrm{O}\right)$, bütün qruplarda dəyişmişdir.

Açar sözlor: Cucurbitaceae, çiçək, morfologiya, bitki aktivatoru, tozcuq

\section{Влияние некоторых активаторов и фунгицидов на морфологию и анатомию пыльцы Cucumis sativus $\mathbf{L}$.}

\section{Айлин Э. Деребойлу}

\section{Улаш Угуз}

Кафедра Биологии, Секция Ботаники, Ғакультет естественных наук, Эгейский университет, 35100-Борнова-Измир, Туричия

В исследовании изучено влияние Forum Blu WP 40 (оксихлорид меди 40\% и диметоморф 6\%), а также исследованы фунгицидов Anvil SC 50 (50 \% гексаконазол) и активатора CropSet на морфологические и анатомические особенности пыльцы Cucumis sativus L. Препараты наносили на проростки C. sativus выращенных в горшках в тепличных условиях в соответствии с рекомендуемой дозой (R.D.) (300 г / 100 л $\mathrm{H}_{2} \mathrm{O}, 40$ куб./ 100 л $\mathrm{H}_{2} \mathrm{O}, 60$ мл / 100 л $\mathrm{H}_{2} \mathrm{O}$ ), R.D.x2 (600 г / 100 л $\mathrm{H}_{2} \mathrm{O}, 80$ куб. См / 100 л $\mathrm{H}_{2} \mathrm{O}, 120$ мл/ 100 л $\mathrm{H}_{2} \mathrm{O}$ ) иR.D.x3 (900 г / 100 л $\mathrm{H}_{2} \mathrm{O}, 120$ см3 / 100 л $\mathrm{H}_{2} \mathrm{O}, 180$ мл / 100 л $\mathrm{H}_{2} \mathrm{O}$ ). Длина и диаметр пыль- цы экваториальным и полярным обзорах, толщина слоев экзин-интины, длина и диаметр пор, длина одной стороны треугольной полярной области на экваториальным обзоре, а также форма пыльцы измерялись с помощью микрометрического окуляра. Контрольная группа и все группы обработки сравнивались в соответствии с полученными данными, наблюдалось увеличение длины и диаметра пыльцы в экваториальном и полярном обзорах, что не соответствовало увеличению дозы. Процент фертильной пыльцы во всех группах обработки снижался по сравнению с контрольной группой, что соответствовало увеличению дозы. В сравнении с контрольной группой слои экзины увеличились, а слои интины уменьшились. Значения длины и диаметра пор, а также длины одной стороны треугольной полярной области увеличились по сравнению с контрольной группой. Было замечено, что аппликации вызывали более токсические эффекты, связанные с увеличением дозы. Причем форма пыльцы, определенная в контрольной группе, изменилась во всех группах, кроме Anvil. (40 мл/100 л $\mathrm{H}_{2} \mathrm{O}$ ) и группы культур (180 мл/100 л $\left.\mathrm{H}_{2} \mathrm{O}\right)$.

Ключевые слова: Cиситbitaceae, иветы, морфология, активатор растений, пыльца 